\section{GALACTION VEREBCEANU}

Institutul de Filologie Română „Bogdan Petriceicu-Hasdeu” (Chişinău)
CZU:811.135.1'366'367:82.09(091)

https://doi.org/10.52505/1857-4300.2021.1(313).06

ORCID: 0000-0002-0725-489

\section{STUDIU LINGVISTIC ASUPRA} MANUSCRISULUI SANDIPA ${ }^{1}$.

MORFOLOGIA (3.1.). SUBSTANTIVUL. ARTICOLUL. ADJECTIVUL. NUMERALUL

\title{
Linguistic STUdy ON THE SANDIPA MANUSCRIPT. Morphology (3.1.). The noun. The article. The aDJective. The numeral
}

\begin{abstract}
The morphological peculiarities of some flexible parts of speech (noun, article, adjective, numeral) present in the text of the popular writing entitled Sandipa (ms. Rom. 824, dated 1798 and kept at the State Library of Russia, Moscow) are analyzed. The forms are examined in terms of the norm existing in the second half of the eighteenth century.
\end{abstract}

Keywords: adjective, article, case, declension, form, gender, number, numeral, noun.

Rezumat. Sunt analizate particularitățile morfologice ale unor părți de vorbire flexibile (substantivul, articolul, adjectivul, numeralul) prezenteîn textul scrierii populare intitulate Sandipa (ms. rom. 824, datat în 1798 și păstrat la Biblioteca de Stat a Rusiei, Moscova). Formele sunt examinate sub aspectul normei existente în a doua jumătate a secolului al XVIII-lea. substantiv.

Cuvinte-cheie: adjectiv, articol, caz, declinare, formă, gen, număr, numeral,

Scopul însemnărilor ce urmează este examinarea trăsăturilor morfologice ale părților de vorbire flexibile substantivul, articolul, adjectivul, numeralul prezente în textul manuscrisului anunţat în titlu. Acestea se remarcă printr-o serie de forme caracteristice perioadei vechi a limbii române, dar și epocii în care a fost copiată versiunea romanului popular de care ne ocupăm. Analiza faptelor de limbă se va face din unghiul de vedere al normei existente în a doua jumătate a secolului al XVIII-lea.

${ }^{1}$ Textul manuscrisului Sandipa a fost publicat, pentru prima dată, integral, în formă de ediție critică (vezi Verebceanu, 2017, p. 35-55; 67-89; 113-130), urmat de trei studii: primul cercetează diverse aspecte filologice (vezi Verebceanu, 2019, p. 49-63), al doilea analizează particularitățile grafiei chirilice (vezi Verebceanu, 2020, p. 93-102), iar al treilea examinează trăsăturile fonetice (vezi Verebceanu, 2020, p. 22-36). 


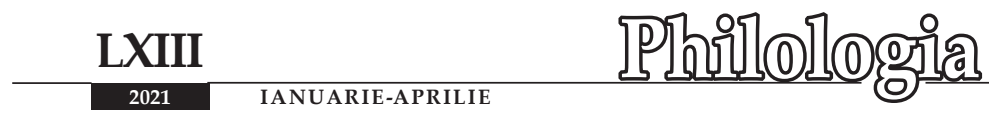

\section{Substantivul}

Substantivul, în calitate de clasă de cuvinte ce ocupă un loc important în sistemul limbii și care este caracterizat ca centru al grupului nominal, prezintă în textul cercetat puține trăsături lingvistice în raport cu cele atestate în primele noastre monumente și documente de limbă română. Rarele forme arhaizante, din punctul de vedere al normei literare actuale, continuă să fie întrebuințate în paralel cu formele noi, acestea din urmă având, de regulă, o frecvență mai mare sau chiar unică și împingând astfel formele vechi spre periferia sistemului. În continuare, vom încerca să determinăm cum se manifestă acest dualism morfologic în textul examinat.

Declinarea. Flexiunea nominală veche caracteristică celor mai vechi texte românești aparţinând secolului al XVI-lea și al XVII-lea (vezi Densusianu, 1961, p. 92-93; ILRL, 1997, p. 113-114) este prezentă, în descreștere, și în textele provenind din a doua jumătate a secolului al XVIII-lea (vezi ILRL, 1997, p. 319-320). Cu referire la textul de care ne ocupăm, consemnăm fenomenul cercetat în două exemple ale actualelor substantive năpastă și peșteră. Primul substantiv menține forma de declinarea a III-a: năpaste $\left(48^{v}\right)$, iar al doilea a trecut la declinarea I: peșteră $\left(28^{\mathrm{r}}\right)$, peștiră $\left(28^{\mathrm{r}}-4\right)$, tendință subliniată de autorii tratatului Istoria limbii române literare: „Formele de declinarea a III-a, mai vechi, abundă mai ales la începutul perioadei $(1640-1780-G$. V.) în special în textele nordice, iar formele de declinarea I, mai noi, se întâlnesc în special în textele sudice" (ILRL, 1997, p. 99-100).

De declinarea a III-a este și substantivul pânticile (23v), cu $e$ trecut la $i$.

Forme noi, deci aparținând declinării I, se constată în substantivele cu radicalul în $s, j$, situație caracteristică mai ales graiului moldovenesc (vezi ILRL, 1997, p. 320): cenuşă (61 $\left.1^{\mathrm{v}}-2,62^{\mathrm{r}}\right)$, mătuşă $\left(36^{\mathrm{r}}, 45^{\mathrm{r}}, 45^{\mathrm{v}}, 47^{\mathrm{r}}-2\right)$, uşă (24v $)$, uşa $\left(24^{\mathrm{v}}\right)$, grijă $\left(15^{\mathrm{v}}, 24^{\mathrm{r}}, 76^{\mathrm{r}}, 100^{\mathrm{v}}\right)$, care nu intră niciodată în alternanță cu formele în -e, curente în textele vechi (vezi Densusianu, 1961, p. 92-93; Rosetti, 1978, p. 547; ILRL, 1997, p. 320), dar și în cele contemporane cu manuscrisul Sandipa (vezi ILRL, 1997, p. 320).

Genul. Substantivul masculin tată prezintă două forme: tatăl (mieu, tău) (4 $4^{\mathrm{v}}, 5^{\mathrm{r}}$ etc.), tată-(său, tău) $\left(6^{\mathrm{v}}-2,9^{\mathrm{v}}-2\right.$ etc., cu 38 de apariții) și tatul $\left(31^{\mathrm{r}}-3,97^{\mathrm{v}}\right.$, $98^{v}$ ), ultima formă - analogică substantivelor masculine de declinarea a II-a terminate în consoană - fiind caracteristică îndeosebi graiului moldovenesc, dar notată şi în textele elaborate în Moldova către sfârșitul secolului al XVIII-lea (vezi nota 2) și, sporadic, în alte zone ale dialectului dacoromân (vezi Gheție, 1975, p. 158; Teodorescu, Gheție, 1977, p. 100). Ambele forme flexionare de nominativ-acuzativ nu sunt concurate niciodată de tătâne decât în genitiv-dativ (vezi infra, Cazul).

La fel masculin este și substantivul pânticile $\left(23^{\vee}\right)$. 
Grăunte este atestat numai ca substantiv de genul neutru: „nici macar un grăunț n-au mâncat" $\left(55^{\mathrm{r}}\right)$, la fel ca în textele redactate în epocă (vezi ILRL, 1997, p. 322), formă cunoscută în perioada 1532-1640. Substantivul slugă este, după terminație, de genul feminin și „,constituie norma epocii” (ILRL, 1997, p. 321): slug $\breve{a}\left(18^{\mathrm{r}}, 21^{\mathrm{r}}, 53^{\mathrm{v}}, 60^{\mathrm{v}}-2\right)$, , ace slug $\breve{a} "\left(24^{\mathrm{r}}, 26^{\mathrm{r}}\right)$, spre deosebire de perioada veche a limbii în care genul substantivului slugă nu apare fixat, fiind întrebuința și ca masculin (vezi Densusianu, 1961, p. 93; Rosetti, 1978, p. 543).

Substantivul de origine autohtonă grumaz nu a păstrat forma de neutru plural în $-e$, trecând în categoria substantivelor masculine, la fel ca în epocă (vezi ILRL, 1997, p. 321): grumazi $\left(60^{\mathrm{v}}\right)$, grumazii $\left(42^{\mathrm{r}}, 60^{\mathrm{v}}\right)$.

Numărul. Forma normală a substantivului copac este cea care păstrează la singular desinența arhaică: copaci $\left(52^{\mathrm{v}}-5,53^{\mathrm{r}}\right)$, copaciul $\left(52^{\mathrm{v}}, 53^{\mathrm{r}}\right)$, copaciului $\left(53^{\mathrm{r}}\right)$, la fel ca în toate textele aparţinând perioadei vechi (vezi Rosetti, 1978, p. 543; ILRL, 1997, p. 120, 324). Forma actuală copac, ,refăcută prin analogie cu drac-draci, sărac-săraci” (ILRL, 1997, p. 120), este posterioară secolului al XVIII-lea.

Substantivul feminin greșeală are desinența de plural $-e$ : greșalele $\left(96^{\mathrm{r}}\right)$; cf. însă bolile $\left(95^{\vee}\right)$, mreji $\left(47^{\vee}\right)$, pricini $\left(77^{\mathrm{r}}\right)$.

Substantivul ochi înregistrează la singular două desinențe, una în - $u$ : ochiu $\left(86^{\vee}, 90^{\vee}\right)$ și alta având desinența zero: ochi $\left(86^{\vee}\right)$.

Pluralul substantivul nume, în cele două atestări, apare în forma nouă: nume $\left(50^{\mathrm{r}}, 51^{\mathrm{r}}\right)$, forma etimologică numere, caracteristică unor texte vechi (vezi, de exemplu, Stanciu-Istrate, 2004, p. 101), nu este cunoscută textului nostru.

Substantivul mână face la plural mâini $\left(65^{\vee}\right)$, mâinile (23 $)$; cf. și mâinule $\left(67^{\mathrm{v}}, 94^{\mathrm{r}}\right)$, un amestec între forma analogică și cea etimologică.

Procesul de înlocuire a desinenței de plural în -e prin cea de $-i$ și desinența în -uri prin cea de $-i$ la unele substantive feminine este prezentă și în textul de care ne ocupăm: frumusețile $\left(13^{\mathrm{v}}, 36^{\mathrm{r}}, 74^{\mathrm{r}}\right)$, ierbi $\left(42^{\mathrm{r}}\right)$, lacrimi $\left(19^{\mathrm{v}}, 34^{\mathrm{v}}, 37^{\mathrm{r}}\right.$ etc. $)$, pricini $\left(77^{\mathrm{r}}\right)$, slugile $\left(27^{\mathrm{v}}-3\right)$; cf. însă vinile $\left(42^{\mathrm{r}}\right)$, cu $e>i$, tendință ce caracterizează textele nordice elaborate în epocă (vezi ILRL, 1997, p. 323-324).

Apariția desinenței - $\breve{a}$ la substantivele cu radicalul în $r$ este atestată în izvoarăle $\left(89^{v}\right)$, formă curentă atât în cele mai vechi texte românești, cât și în textele contemporane cu manuscrisul Sandipa (vezi Densusianu, 1961, p. 99; Rosetti, 1978, p. 547; ILRL, 1997, p. 121; 325). Acestui unic exemplu i se opune substantivul $h<i>$ arile $\left(76^{\vee}\right)$, cu $e$ închis la $i$.

Desinența de plural singular a neutrelor terminate în consoană sau în $-u$ este -uri, niciodată -ure: ceasuri $\left(4^{v}\right)$, gânduri $\left(15^{\mathrm{r}}\right)$, vicleșuguri $\left(55^{\mathrm{r}}\right)$ etc.

Într-un caz, substantivul pasăre apare la plural fără modificarea vocalică a radicalului (nu a avut loc alternanța vocalică): pasările $\left(76^{\vee}\right)$.

Cazul. Substantivul tată, urmat de adjective posesive, înregistrează la genitiv-dativ exclusiv forma tătâne: al tătâne-său $\left(31^{\mathrm{r}}\right)$, tătâni-m(i)eu $\left(27^{\mathrm{r}}, 32^{\mathrm{r}}\right.$, 


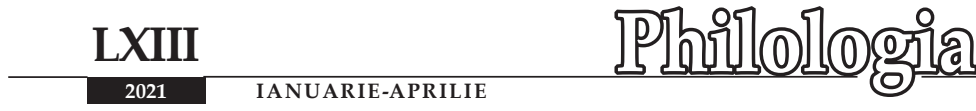

$\left.69^{v}\right)$, tătâni-tău $\left(6^{\mathrm{v}}, 28^{\mathrm{v}}\right)$, tătâne-său $\left(5^{\mathrm{r}}, 15^{\mathrm{r}}, 33^{\mathrm{r}}, 99^{\mathrm{r}}\right)$, fonetism caracteristic textelor contemporane ${ }^{2}$ cu manuscrisul de care ne ocupăm.

Substantivul stăpân, indicând relații sociale, este însoțit de adjectivul posesiv conjunct și apare notat fie la dativ în formă feminină omonimă cu nominativul: „nimică n-au spus stăpână-său” (17 $\left.7^{\vee}\right)$, ,spusă stăpână-său” $\left(84^{\mathrm{r}}\right)$, fie la nominativ: „vine stăpână-său” (24v), ,să nu-1 priceapă stăpână-său” (24v) - construcție simțită astăzi ca fenomen regional (vezi GALR, I, 2005, p. 95) -, fie întărit de prepoziția la: ,,au adus la stăpână-său $\left(22^{r}\right)$.

Substantivul feminin de origine ucraineană cuşcă apare întrebuințat la genitivdativul singular, în cele două exemple, sub forma învechită cușcii $\left(18^{\mathrm{r}}-2\right)$.

Substantivul în genitiv-dativ este concurat de construcții prepoziționale, răspândite în epocă mai ales în textele nordice (vezi ILRL, 1997, p. 326). Cele mai frecvente sunt construcțiile prepoziționale cu cătră și la, echivalente cu dativul: „Zisă dascalul cătră cucon” ( $\left.5^{\mathrm{r}}\right)$, „Şi dând şi mare giurământ ea cătră cucon” $\left(9^{v}\right)$, ,am grăit cătră dânsul” (57 $)$, „Sandipa ră<spu>nsă cătră împăratul” (72 $)$, „strigă cătră tovarăş" $\left(79^{v}\right)$, „Voi da pre fiiul mieu la Sandipa filosoful” $\left(2^{r}\right)$, „au poroncit la tatul mirilui” (31 $)$, „făcut-au câte 2 haine la tot" (50), „să o arunci la câini” (94'), ,voinicul închină colacii la împăratul” $\left(99^{v}\right)$. În două contexte apare construcția prepozițională cu $a$, echivalentă cu genitivul: ,scrisă şi istoriile $a$ câte învăţături vre să-1 înveță” $\left(3^{v}\right)$, ,este ajutoriu şi păzitoriu $a$ tot omul" $\left(71^{1}\right)$. Nu lipsesc însă nici construcții sintetice de felul: „după zapis ce au dat împăratului" $\left(6^{\mathrm{r}}\right)$, „să închină impăratului” $\left(6^{\vee}\right)$, ,grăiem fiiului tău” (11 $)$, „Această pildă spusă filosoful cel dintâi impăratului” $\left(16^{v}\right)$, ,pasărea păpăgalul au spus stăpânului toate" $\left(17^{\vee}\right)$ etc.

Numele propriu Sandipa formează genitiv-dativul atât pe cale sintetică: Sandipii $\left(3^{\mathrm{r}}, 3^{\mathrm{v}}, 72^{\mathrm{r}}, 73^{\mathrm{r}}, 93^{\mathrm{r}}, 96^{\mathrm{v}}, 101^{\mathrm{r}}\right)$, Sandipei $\left(3^{\mathrm{v}}\right)$, Sandipăi $\left(71^{\mathrm{v}}\right)$, cât și analiticosintetică: a lui Sandipii $\left(1^{\mathrm{r}}\right)$, precum și cu ajutorul prepozițiilor către și la: „zisă împăratul cătră Sandipa” (2v), „voi da pre fiiul mieu la Sandipa filosoful” ( $\left(2^{r}\right)$.

Dumnezeu, prin cele 14 atestări, prezintă la cazul oblic exclusiv forma analitică: lui Dumnezeu $\left(1^{\mathrm{v}}, 28^{\mathrm{v}}, 44^{\mathrm{v}}, 72^{\mathrm{r}}\right.$ etc).

Acuzativul cu funcție sintactică de complement direct al substantivelor exprimate, la fel ca în limba actuală, prin nume proprii, nume comune de ființă sau prin substitute (pronume personal ori, mai rar, pronume relativ) apare însoțit de $p(r) e$ : „chemă pe Sandipa” (2'), ,adusă pe fiul său” $\left(69^{1}\right)$, ,pe mine mă vei avea fimei ţie" $\left(10^{\mathrm{r}}\right)$, ,pe dânşii nu i-au chemat" $\left(12^{\mathrm{r}}\right)$, „, care pe care va birui din vorbe” $\left(89^{\vee}\right)$, „pe cine îl dor dinţii” $\left(95^{\vee}\right)$ etc. Prepoziția $p(r)$ e însoțește uneori și un substantiv din subclasa animalelor, păsărilor și reptilelor ,personalizate, în condițiile individualizării puternice a substantivului-complement” (GALR, II,

\footnotetext{
${ }^{2}$ Se are în vedere Alexăndria lui Năstase Negrule, manuscris ieșean de la 1790, recent editat în condiții tipografice excelente, în care sunt atestate forme ca tatul $\left(5^{v}\right)$ și tătâne-său $\left(11^{\mathrm{r}}\right)$ (vezi Dumitrescu, 2015).7
} 
2005, p. 377): ,acel tălhariu birui şi pre leu şi pre momiţă” (53), „învăţă pe taină stăpânul pe pasăre”, ,apucă pe un șarpe” $\left(75^{\vee}\right)$.

Dintre vocative, mai răspândite sunt cele etimologice terminate în -e, pentru masculin singular: bărbate $\left(57^{\mathrm{r}}, 63^{\mathrm{r}}, 66^{\mathrm{r}}, 66^{\mathrm{v}}, 67^{\mathrm{r}}\right)$, cucoane $\left(9^{\mathrm{v}}, 31^{\mathrm{v}}\right)$, dascale $\left(6^{\mathrm{r}}, 87^{\mathrm{v}}\right.$, $90^{\mathrm{v}}$ etc. $)$, Doamne $\left(29^{\mathrm{r}}, 80^{\mathrm{v}}, 82^{\mathrm{r}}\right.$ etc. $)$, frate $\left(84^{\mathrm{v}}, 85^{\mathrm{r}}\right)$, giupâa $(i)$ ne $\left(18^{\mathrm{v}}, 22^{\mathrm{v}}\right)$, împărate $\left(2^{\mathrm{v}}, 21^{\mathrm{r}}, 70^{\mathrm{r}}\right.$ etc. $)$, oame $\left(35^{\mathrm{r}}\right)$, priiatine $\left(90^{\mathrm{v}}\right)$, stăpâine $\left(22^{\mathrm{v}}\right)$, voinice $\left(38^{\mathrm{v}}-2,39^{\mathrm{r}}, 49^{\mathrm{r}}\right.$, $\left.67^{\mathrm{r}}\right)$ și pentru feminin singular: fimei, cu $e>i\left(10^{\mathrm{r}}, 69^{\mathrm{r}}, 81^{\mathrm{r}}, 82^{\mathrm{v}}\right)$, muiere $\left(56^{\mathrm{v}}, 58^{\mathrm{r}}\right.$, $\left.71^{\mathrm{v}}, 80^{\mathrm{v}}, 83^{\mathrm{r}}\right)$ sau vocativele identice cu nominativul articulat, urmate de adjectivul posesiv: fătul (mieu) $\left(4^{\mathrm{v}}, 81^{\mathrm{r}}, 81^{\mathrm{v}}, 82^{\mathrm{r}}-2,91^{\mathrm{v}}\right)$, fiul (mieu) $\left(77^{\mathrm{r}}\right)$, tatăl (mieu) $\left(4^{\mathrm{v}}\right)$. Mai puține la număr sunt vocativele în -ule: fiiule $\left(75^{\mathrm{r}}, 98^{\mathrm{v}}\right)$, omule $\left(16^{\mathrm{r}}, 61^{\mathrm{v}}, 84^{\mathrm{v}}\right.$ etc.). Pentru formele de feminin singular apar atât vocativele în $-o$ : babo $\left(48^{\mathrm{v}}, 80^{\mathrm{r}}\right.$, $\left.80^{\mathrm{v}}\right)$, maico $\left(38^{\mathrm{r}}, 79^{\mathrm{r}}, 79^{\mathrm{v}}-2,81^{\mathrm{v}}\right)$, cât și cele identice cu nominativul: maică $\left(78^{\mathrm{v}}\right.$, $\left.79^{\mathrm{v}}, 85^{\mathrm{v}}\right)$, mătuşă $\left(36^{\mathrm{r}}, 45^{\mathrm{r}}, 45^{\mathrm{v}}, 47^{\mathrm{r}}-2\right)$. Nu lipsesc nici vocativele de plural masculin echivalente cu dativul : filosofilor $\left(73^{\mathrm{r}}, 75^{\mathrm{v}}\right)$, fraților $\left(65^{\mathrm{r}}, 66^{\mathrm{r}}, 95^{\mathrm{v}}\right)$, vecinilor $\left(64^{\mathrm{v}}\right)$.

Structura de vocativ constând din doi și mai mulți termeni este folosită frecvent: „(pre)puternice impărate” $\left(4^{\mathrm{v}}, 13^{\mathrm{r}}, 21^{\mathrm{v}}, 70^{\mathrm{v}}\right.$ etc.), ,fiule preiubite” $\left(70^{\mathrm{v}}\right)$, „iubite fiule" $\left(100^{\mathrm{r}}\right)$, ,preluminate părintile mieu" $\left(91^{\mathrm{v}}\right)$, ,părintile meu împărate” $\left(78^{\mathrm{r}}, 83^{\mathrm{v}}, 91^{\vee}\right)$, „,mult puternice împărate şi al mieu dulci părinte” $\left(74^{\vee}\right)$, ,păcătosule şi prăpădite oame" $\left(39^{v}\right)$, construcții învechite și restrictive sub raportul normei românei literare actuale (vezi GALR, I, 2005, p. 149).

\section{Articolul}

Articolul hotărât enclitic masculin $-l$ este notat constant: cuconul $\left(6^{v}\right)$, filosoful $\left(1^{\mathrm{r}}\right)$ etc. Lipsa ${ }^{3}$ articolului este atestată în unele contexte ale substantivului obicei: „după obiceiu filosofesc” $\left(6^{v}\right)$, ,ave (el) obiceiu” $\left(8^{v}, 41^{v}, 83^{v}\right)$, „,ei au obiceiu” $\left(87^{1}\right)$. În alte situații, acelaşi substantiv este întrebuințat în mod obișnuit: „după obiceiul filosofesc” $\left(13^{\mathrm{r}}\right)$, „din obiceiul cetățenilor” $\left(86^{\mathrm{r}}\right)$.

Absența articolului hotărât $-i$ - reflex al limbii vorbite - se constată la genitiv-dativul singular al substantivului propriu Persia: Perşii $\left(57^{v}\right)$ și, frecvent, al substantivelor comune feminine: astronomii $\left(5^{\vee}\right)$, culivii $\left(18^{\mathrm{r}}\right)$, culevii $\left(18^{\mathrm{v}}\right)$,

${ }^{3}$ Cauza dispariției lui - $l$, des întâlnită în perioada veche a limbii române (vezi Densusianu, 1961, p. 100; Rosetti, 1978, p. 550-551; ILRL, 1997, p. 124), ,poate să se datorească în unele cazuri neatenției copiştilor sau deprinderii lor de a scrie o singură dată litere care se repetau la sfîrșitul unui cuvînt și la începutul cuvîntului următor $<\ldots$.. > Rămîn însă un număr mare de cazuri care par să arate că - $l$ începuse să nu mai fie pronunțat $<\ldots>$ (Densusianu, 1961, p. 109). O altă ipoteză a fost emisă de Al. Rosetti: ,În limba vorbită de astăzi articolul enclitic masc. de nominativ-acuzativ $-l$ a dispărut: omu (<omul); locul lui -l este ținut de $-u$, formîndu-se o alternanță morfologică nouă: zero/u (om/ omu)" (Rosetti, 1978, p. 551), supoziție reluată într-un fel de autorii tratatului Istoria limbii române literare. Epoca veche (1532-1780), care interpretează fenomenul ,ca urmare a tendinței generale de preluare a funcției articolului de -u” (ILRL, 1997, p. 327). 


\section{LXIII \\ 2021 \\ IANUARIE-APRILIE

filosofii $\left(77^{\mathrm{v}}\right)$, istorii $\left(101^{\mathrm{r}}\right)$, impărăţii $\left(54^{\mathrm{r}}\right)$, primejdii $\left(59^{\mathrm{r}}, 73^{\mathrm{r}}\right)$, viclenii $\left(93^{\mathrm{v}}\right)$, în genitiv-dativul sintagmei împărăția ta: împărăţii tale $\left(4^{\mathrm{v}}, 30^{\mathrm{v}}, 93^{\mathrm{r}}\right.$ etc.), precum și în singurul caz al locuțiunii pronominale Măria Ta: Mării Tale (83v).

Articolul proclitic de genitiv-dativ masculin singular lui apare notat înainte de substantivele proprii: „lui Dumnezeu” $\left(1^{\mathrm{v}}, 28^{\mathrm{v}}, 44^{\mathrm{v}}, 72^{\mathrm{r}}\right.$ etc.), „lui Chir-Împărat” $\left(1^{\mathrm{r}}, 101^{\mathrm{r}}\right)$, varianta $l u$ în manuscrisul de care ne ocupăm nu este folosită; este folosită însă curent, alături de lui, în mai multe texte aparținând secolelor al XVI-lea-al XVIII-lea (vezi Rosetti, 1978, p. 551-552; ILRL, 1997, p. 124, 327; Gheție, Teodorescu, 2005, p. 43; Chivu, 1993, p. 178).

Articolul posesiv-genitival cunoaște o întrebuințare destul de frecventă, forma variabilă intrând, uneori, în alternanță cu forma invariabilă, situație proprie atât textelor provenind din secolul al XVI-lea (vezi Densusianu, 1961, p. 109; Rosetti, 1978, p. 553-554; ILRL, 1997, p. 124-125), cât și textelor din epoca elaborării manuscrisului Sandipa. Repartizarea teritorială a fenomenului este următoarea: „Formele variabile ale articolului posesiv genitival rămân o trăsătură a textelor sudice, în timp ce forma invariabilă rămâne caracteristică a textelor nordice, care însă foloseau uneori și forme variabile" (ILRL, 1997, p. 327). O asemenea utilizare a articolului posesiv-genitival se regăsește și în textul nostru. Iată, de pildă, unele exemple de forme variabile: „copil al...” $\left(20^{1}\right)$, „,cuvântul

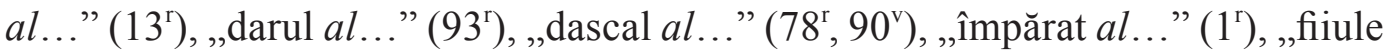

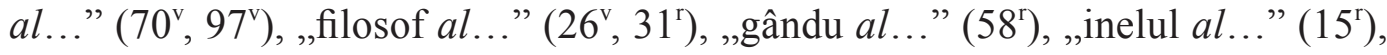

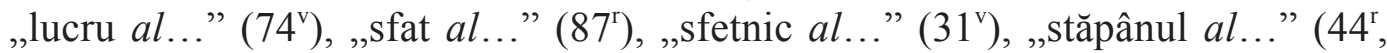

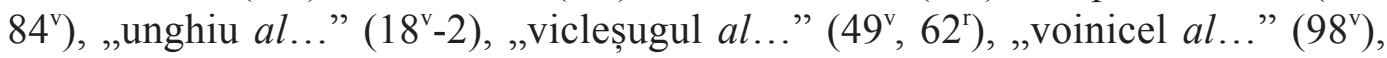

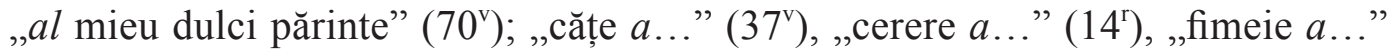
$\left(65^{\mathrm{r}}\right)$, „fire $a \ldots$. $\left(92^{\mathrm{r}}\right)$, ,istorie $a \ldots$.. $\left(83^{\mathrm{v}}\right)$, ,învăţătură $a \ldots$.. $\left(8^{\mathrm{r}}\right)$, ,margine $a \ldots$... $\left(84^{\mathrm{r}}\right)$, ,minte $a \ldots$ " $\left(75^{\mathrm{r}}\right)$, ,naștire $a \ldots$ " $\left(100^{\mathrm{r}}\right)$, , $a$ me osârdie" $\left(97^{\mathrm{r}}\right)$, ,poroncă $a \ldots$..,

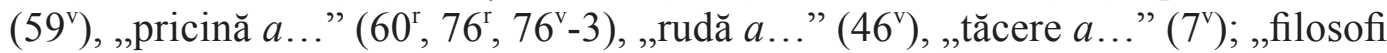

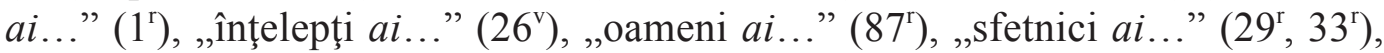
„toț ai casăi” (50 $)$; „meșteșugurile ale ...” $\left(61^{\mathrm{r}}\right)$, ,vicleșuguri ale ...” $\left(55^{\mathrm{v}}\right)$, „,vorbe ale..." $\left(14^{\mathrm{v}}, 93^{\mathrm{v}}\right)$, ,de ale casăi” $\left(50^{\mathrm{r}}\right)$.

Forma invariabilă, mai puțin numeroasă, apare în contexte ca: „cuvântul

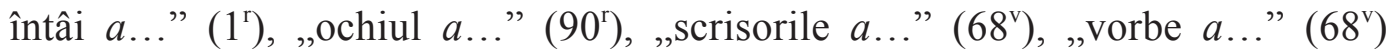
etc. Alteori, prioritate se dă formei $a l$, fiind consemnat așa-numitul acord fals:

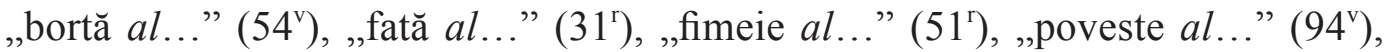
„pricină al...” (73' $\left., 74^{\mathrm{v}}, 76^{\mathrm{v}}-2\right)$, ,slugă (f.) al...” (24r), ,slujnică al...” $\left(17^{\mathrm{r}}, 84^{\mathrm{r}}\right)$, „învăţăturii al ..." (71 $)$, al râmătorilor şi al cailor pohte" $\left(14^{\mathrm{r}}\right)$, ,al curvilor sfaturi şi al muierilor $\left(30^{v}\right)$.

În două cazuri, articolul posesiv-genitival apare notat după un substantiv articulat, întrebuințare superfluă în raport cu norma limbii actuale: „va învăţa

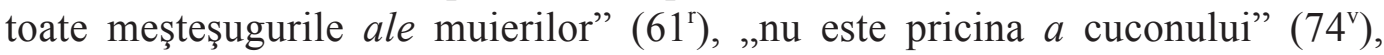


construcție uzuală însă în textele din secolul al XVI-lea (vezi Densusianu, 1961, p. 245-246).

Articolul demonstrativ-adjectival cunoaște o topică obișnuită, plasat între un substantiv și adjectiv: „filosoful cel mare” $\left(26^{v}\right)$, ,pasire ce dreaptă” (19 $)$, „sfetnicii tăi cei răi” (31'), „lucrurile cele bune” $\left(100^{1}\right)$ sau apare în prepoziție absolută, însoțind fie un adjectiv pe care îl substantivează: „,cele înțelepte” $\left(51^{\mathrm{r}}\right)$, fie un adjectiv invariabil: ,ce dintâi răutate” $\left(23^{v}\right)$, fie un numeral cardinal: „cei doi” $\left(79^{\mathrm{r}}\right)$, ,cele 6 zile" $\left(58^{\mathrm{v}}\right)$.

La genitiv-dativ articolul demonstrativ-adjectival se acordă în caz cu substantivul: „un fiiu al filosofului celui mai mare” $\left(97^{\vee}\right)$,al muierilor celor rele” $\left(30^{v}\right)$, ,preţul lemnelor celor mirositoare” $\left(91^{1}\right)$. Într-un caz, apare forma etimologică: „o slujnică al cei jupenesă" $\left(17^{\mathrm{r}}\right)$.

Articolul nehotărât, alături de formele întâlnite și astăzi: un (94`); cf. însă forma dialectală on $\left(17^{\mathrm{v}}\right), o\left(84^{\mathrm{r}}\right)$, niște $\left(63^{\mathrm{v}}\right)$, niciodată nește, înregistrează, pentru genitiv-dativ feminin singular a articolului $o$, singura formă unii, fenomen atestat în cele mai vechi texte românești (vezi Densusianu, 1961, p. 114): „unii momiți” $\left(51^{v}\right)$, ,unii muieri” $\left(68^{v}, 69^{\mathrm{r}}, 70^{v}\right)$, ,unii porumbiță” $\left(54^{v}\right)$, ,unii vulpi” $\left(94^{v}\right)$.

\section{Adjectivul}

Adjectivul, sub raportul flexiunii, cunoaște puține trăsături demne de luat în seamă. Astfel, mare are câteodată la plural formă identică cu singularul, situație întâlnită în cele mai vechi texte românești (vezi Densusianu, 1961, p. 108; Rosetti, 1978, p. 550; Moraru, 1996, p. 98), iar în epoca elaborării textului fenomenul caracterizează ,unele texte nordice” (ILRL, 1997, p. 328): „mare gânduri” (86 ), „,mare păcate" $\left(9^{v}\right)$.

Pluralul în $-i$, același ca în limba actuală, câștigă din ce în ce mai mult teren: „dulci cuvinte” ( $\left.3^{\mathrm{r}}\right)$, , mari bucurii” $\left(70^{\mathrm{v}}\right)$, ,mari nebuni” $\left(26^{\vee}\right)$.

Adjectivul nou are la feminin singular forma curentă în textele vechi: ,casă, mare noao" $\left(100^{7}\right)$, iar diminutivul de genul feminin numărul singular al lui puțin apare notat în forma ,puțunte fãină” $\left(49^{1}\right)$.

Referitor la gradele de comparație ale adjectivului, este de subliniat faptul că, în linii mari, acestea nu se deosebesc de cele din limba actuală. De exemplu, comparativul de superioritate este exprimat exclusiv, în singurul exemplu, cu ajutorul adverbului decât: „dulceaţă mai dulce decât miere” (38v), niciodată cu de, cum se întrebuința în textele vechi (vezi Rosetti, 1978, p. 550; Vieru, 2014, p. 66). Superlativul absolut se construiește cu ajutorul adverbelor foarte, mult și prea, primul plasat în prepoziție (niciodată în postpoziție, cum apare când are valoare adverbială), al doilea și al treilea, mult și prea, având, învechit și regional, sensul „foarte”, ultimul, cu monoftongarea diftongului: ,dascal foarte inţelept” ( $1^{\mathrm{v}}$ ), „muiere foarte frumoas ă " $\left(13^{\vee}\right)$; , găsi borta mult deşartă” $\left(55^{\mathrm{r}}\right)$; , precurvariul acela” $\left(45^{\mathrm{r}}\right)$, „Solomon preînţeleptul” $\left(50^{\mathrm{r}}\right)$,preînţeleaptă" $\left(14^{\mathrm{r}}, 45^{\mathrm{r}}\right)$, ,preînţelepților 


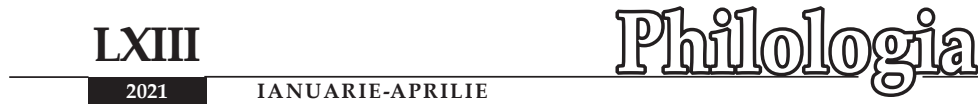

domni” $\left(94^{v}\right)$, ,preluminate părintile mieu” $\left(92^{v}\right)$, ,preputernice împărate” $\left(13^{\mathrm{r}}, 17^{\mathrm{r}}\right.$, $\left.93^{\vee}\right)$, „fiiule preiubite” $\left(70^{v}\right)$, ,fiiule preiubite al mieu” $\left(70^{v}\right)$, ,un rău pre mare” $\left(60^{v}\right)$, „aceii muieri precurve” $\left(70^{1}\right)$ etc.

\section{Numeralul}

Numeralul cardinal propriu-zis, simplu sau compus, nu se deosebește, în linii generale, de cel folosit în limba română literară actuală. Ceea ce îl diferențiază sunt unele forme care păstrează fonetismul arhaic, precum și faptul că grafia chirilică folosea, după modelul alfabetului limbii grecești, redarea valorii numerice cu ajutorul unor slove. Textul cercetat atestă numerale cardinale notate atât prin slove-cifră, având o frecvență mare (53 de atestări): „3 ani” $\left(2^{1}\right)$, ,4 luni”

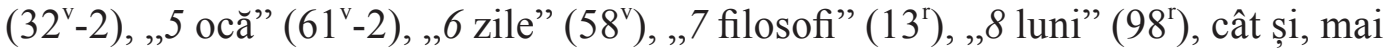
rar, prin litere: „numai un bărbat şi o fimeie” $\left(74^{r}\right)$, ,doi ochi” $\left(86^{\vee}\right)$, „trii ani”" $\left(91^{\mathrm{v}}\right.$; vezi și $46^{\mathrm{r}}, 48^{\mathrm{r}}, 60^{\mathrm{v}}-2,78^{\mathrm{v}}$ etc. $)$, „tri ceasuri” $\left(4^{\mathrm{v}}\right)$, „cinci ani” $\left(81^{\mathrm{r}}\right)$, ,„sapte zile" $\left(10^{\mathrm{r}}-2,69^{\mathrm{v}}\right)$.

Numeralul cardinal compus este exprimat exclusiv prin slove-cifră: „13 ani” $\left(97^{\vee}\right),, 15$ ani” $\left(98^{v}\right)$, cardinalul mai mare de 20 fiind urmat de prepozitia de, la fel ca în limba de astăzi: „,150 de zile” $\left(62^{\mathrm{r}}\right)$. Reprezentarea valorii numerice prin cifre arabe, ca în limba română literară actuală, nu este folosită în text.

Aproximația cantitativă a numeralului cardinal este exprimată prin alăturarea numeralelor vecine 2 și 3 , cu omiterea substantivului regent, subînțeles însă din context: „să întâmplă 2-3 întru un loc” $\left(77^{\mathrm{r}}\right)$.

Numeralul ordinal este reprezentat, pentru primul termen, de forma analogică intâi: „,cuvântul întâi”" $\left(1^{\mathrm{r}}\right)$, ,pilda filosofului întâi” $\left(13^{\mathrm{v}}\right)$. Forma etimologică, întâie, răspândită în textele din secolul al XVI-lea (vezi Densusianu, 1961, p. 115; Gheție, Teodorescu, 2005, p. 44), nu este cunoscută manuscrisului Sandipa.

Sinonimul lui întâi este compusul cu de, dintâi, asociat cu cel, cea, având valoare adjectivală și cu ordinalul postpus substantivului în cele două apariții: „dascalul cel dintâi”" $\left(91^{v}\right)$,„pilda ce dintâi” (21 $)$; cf. însă și ,ce dintâi răutate” $\left(23^{v}\right)$.

Numeralele ordinale pentru celelalte cardinale se prezintă sub mai multe forme și au, pentru masculin, următoarea structură: al + numeralul cardinal, exprimat prin slove-cifră $+l e$, dar fără particula $-a$, fenomen întâlnit în a doua jumătate a secolului al XVIII-lea, în primul rând în textele moldovenești (vezi ILRL, 1997, p. 333; vezi și GALR, I, 2005, p. 305). În cazul în care ordinalul este notat doar prin slove-cifră, secvența -lea nu apare, întrebuințare folosită în mai multe texte vechi (vezi Vieru, 2014, p. 71): „al 3 filosof” (73 ${ }^{v}$ ), „al 4 filosof” $\left(35^{\mathrm{v}}, 40^{\mathrm{v}}, 73^{\mathrm{v}}\right)$, , al 5 filosof” $\left(42^{\mathrm{v}}\right)$, ,al 6 filosof” $\left(53^{\mathrm{v}}\right)$, „,Pilda filosofului al $6\left(54^{\mathrm{v}}\right)$, , al 7 filosof” $\left(59^{\mathrm{r}}-2,69^{\mathrm{r}}\right)$. În două exemple, ordinalul este exprimat, învechit și regional, prin formele: ,al treile filosof” $\left(29^{v}\right)$, „Aceşti şi cu altul, al triile" $\left(82^{\prime}\right)$, în ultimul caz, cu omiterea substantivului. 
Sunt consemnate și construcții, învechite și regionale, cu acord mixt, greșit din punctul de vedere al normei limbii contemporane: , al 5 zi” $\left(40^{v}\right)$, ,al 6 zi” (53v); vezi și ordinalul masculin pentru patru, care apare în formă feminină: ,al patra filosof" $\left(33^{\mathrm{v}}\right)$.

Ordinalul feminin apare notat, la fel ca cel masculin redat cu slove-cifră, fără

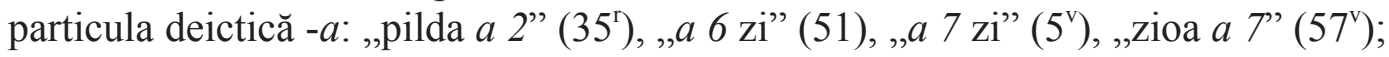
vezi și, învechit și regional, ,a trie zi” (66); cf. însă ,a patra zi” $\left(31^{\mathrm{r}}\right)$, ,a opta zi” $\left(69^{r}\right)$. Intr-un caz, ordinalul feminin nu este acordat cu substantivul regent, rezultând un reflex al construcției arhaice: ,a patra filosof' $\left(76^{\mathrm{r}}\right)$.

Numeralul colectiv. Dintre formele acestei clase de cuvinte consemnăm amândoi (niciodată îmbii): ,aşa şide numai amândoi" (4 $4^{\mathrm{r}}$; vezi și $35^{\mathrm{v}}-2,55^{\mathrm{r}}, 74^{\mathrm{r}}$ etc.) și tustrei, ultimul întrebuinţat în variante astăzi regionale: „mearsără întru un târg pentru negustorie tustrii” (78v'; vezi și $\left.82^{\mathrm{v}}-4\right)$, ,zisără trustrii” $\left(82^{\mathrm{v}}\right)$, ,până nu vom fi trustei” $\left(80^{\mathrm{r}}, 81^{\mathrm{r}}\right.$; vezi și $\left.79^{\mathrm{r}}\right)$, „până nu-ţ fi trusteii tovarăşii” $\left(79^{\mathrm{r}}\right)$, ,„le dediră trusteli" $\left(78^{v}\right)$.

Numeralul multiplicativ apare notat, în singurul exemplu, cu fonetismul regional -iit: ,,ii dedi întriit preţul lemnelor” $\left(91^{\mathrm{r}}\right)$.

Numeralul distributiv, prin nimic deosebitor de cel din limba actuală, este înregistrat în exemplele: „să meargă în toate zilile câte unul” $\left(12^{\mathrm{v}}, 56^{1}\right)$, ,câte $o$ pungă” $\left(78^{v}\right)$, „făcut-au câte 2 haine” $\left(50^{r}\right)$.

Generalizând descrierea trăsăturilor morfologice ale claselor de cuvinte flexibile ca: substantivul, articolul, adjectivul și numeralul înregistrate în textul romanului popular Sandipa, se poate constata faptul că limba română de la sfârşitul secolului al XVIII-lea înregistrează o evidentă tendință de simplificare şi reducere a formelor arhaizante, favorizând întrebuinţarea celor noi, care vor fi acceptate ulterior de norma limbii literare. Mai mult, inovațiile fac concurență în unele cazuri încă timidă, alteori destul de evidentă - formelor vechi sau chiar înlocuindu-le pe acestea. Astfel, peșteră, dar năpaste; numai ușă, grijă menținerea încă a formelor tatul, un grăunțt, grumazi, copaciul; pricini, dar și graşale; mâinile, însă mâinule; izvoarăle; cf. însă $h<i>$ arile; Sandipii; cf. lui Sandipii; omule, dar oame; al, a, ai, ale a; mari bucurii, însă mare păcate; foarte frumoasă, dar mult deșartă și preiubite; al $3<-l e a>$ și al treile; tustrii, trustei și trusteli.

\section{Referinţe bibliografice:}

CHIVU, Gheorghe. Codex Sturdzanus. Studiu filologic, studiu lingvistic, ediție de text și indice de cuvinte de Gheorghe Chivu. București, 1993.

DENSUSIANU, Ovid. Istoria limbii române. Vol. II. Secolul al XVI-lea. Ediție îngrijită de prof. univ. J. Byck. București, 1961. 
Dumitrescu, 2015 = Istoria lui Alexandru cel Mare: Alexandria ilustrată de Năstase Negrule. Coordonator: Gabriela Dumitrescu. București: Sapienția Principium Cognitio, 2015.

GALR, I = Gramatica limbii române. I. Cuvântul. București, 2005.

GALR, II = Gramatica limbii române. II. Enunțul. București, 2005.

GHEȚIE, Ion, TEODORESCU, Mirela. Psaltirea Hurmuzaki. I. Studiu filologic, studiu lingvistic și ediție de Ion Gheție și Mirela Teodorescu. București, 2005.

GHET,IE, Ion. Baza dialectală a românei literare. București, 1975.

ILRL = Istoria limbii române literare. Epoca veche (1532-1780) de Gheorghe Chivu, Mariana Costinescu, Constantin Frâncu, Ion Gheţie, Alexandra Roman Moraru şi Mirela Teodorescu. Coordonator: Ion Gheție. București, 1997.

MORARU, Alexandra. Floarea darurilor. Text stabilit, studiu filologic și lingvistic, glosar de Alexandra Moraru. În: Academia Română. Institutul de Lingvistică „Iorgu Iordan". Cele mai vechi cărți populare în literatura română. Coordonatori: Ion Gheție și Alexandru Mareș. I. București, 1996, p. 5-193.

ROSETTI, Al. Istoria limbii române. 1. De la origini pînă la începutul secolului al XVII-lea. Ediţie definitivă. București, 1978.

STANCIU-ISTRATE, Maria. Viața sfântului Vasile cel Nou și vămile văzduhului. Studiu filologic, studiu lingvistic, ediție și glosar de Maria Stanciu-Istrate. În: Academia Română. Institutul de Lingvistică „, Iorgu Iordan- Al Rosetti”. Cele mai vechi cărți populare în literatura română. Coordonatori: Ion Gheție și Alexandru Mareș. II. București, 2004.

TEODORESCU, Mirela, GHET,IE, Ion. Manuscrisul de la Ieud. Text stabilit, studiu filologic, studiu de limbă şi indice de Mirela Teodorescu, Ion Gheție. Bucureşti, 1977.

VEREBCEANU, Galaction. Considerații filologice asupra manuscrisului Sandipa. În: Philologia. 2019, nr. 3-4, p. 49-63.

VEREBCEANU, Galaction. Studiu lingvistic asupra manuscrisului Sandipa. Grafia (1). În: Philologia. 2020, nr. 3-4, p. 93-102.

VEREBCEANU, Galaction. Studiu lingvistic asupra manuscrisului Sandipa. Fonetica (2). În: Philologia. 2020, nr. 5-6, p. 22-36.

VEREBCEANU, Galaction. Un manuscris al Sindipei de la sfârșitul secolului al XVIII-lea. Text. În: Philologia. 2017, nr. 1-2, p. 35-55, nr. 3-4, p. 67-89, nr. 5-6, p. 113-130.

VIERU, Roxana. Studiu lingvistic asupra Paliei de la Orăștie. Iași: Editura Universității „Al. I. Cuza”, 2014.

Notă: Articolul a fost realizat în cadrul proiectului de cercetare 20.80009.1606.01 Valorificarea științifică a patrimoniului lingvistic național în contextul integrării europene, Institutul de Filologie Română „B. P.-Hasdeu” al MECC. 